\title{
American Stars'n'bards, and Swedish Reviewers: The Swedish Field of Literary Criticism and the Local Symbolic Reproduction of Global U.S. Authors
}

\section{Bo G. Ekelund}

Stockholm University

\begin{abstract}
This article looks at the way U.S. authors were received by Swedish practical criticism in the period 1980-2005. After a quantitative overview of the U.S. authors and genres that were given attention in Swedish review media in this period, the article discusses discrepancies between the original U.S. and the Swedish recognition. One particularly interesting case is the very favorable reception of Paul Auster's work, which functioned as a confirmation of the postmodern breakthrough in the Swedish literary field. What the introduction of Auster shows is how Swedish critics function as intermediaries who represent what Pascale Casanova has identified as the "national" and the "international" poles of the literary field. Since Swedish criticism is in the peculiar position of representing a peripheral literary field that nevertheless controls a central consecrating instance, the Nobel Prize, it can be argued that the strategies of the most autonomous critics are always to some extent oriented in relation to the struggles between the world literary centers. The Swedish critic Aris Fioretos' introduction and intraduction of Paul Auster is, in that regard, a pertinent illustration of the cosmopolitan trajectory required for the fulfillment of the role of introduktör ("introducer"), a particularly significant function in a field that contains the Prize-awarding Academy.
\end{abstract}

Keywords: Field of criticism-Pascale Casanova, theories of-Paul Auster, U.S. author-postmodernism, in the U.S. and Sweden-practical criticism-reception study-transnational literature-world literary space 
The allusion to Lord Byron's satirical poem "English Bards and Scotch Reviewers" in the title is almost purely ornamental, but, as in that satire, what is of interest to us here is a relation between authors whose works originate in one national literary field and critics who belong to another. ${ }^{1}$ It is the "mingled howl / Of Northern Wolves" that will be investigated here, as much as the literary matters they howl over. In other words, this article is a reception study ${ }^{2}$ that takes the internal relations between the receivers - the critics - to be at least as important as the meanings the literary works are given in their new context. Swedish taste is not in a position to decide on US wit, to travesty Byron; nor, as we will see, does American literature exercise any straightforward influence over the judgments made by Swedish reviewers. However, U.S. works of fiction, and the authorships they represent, form an important resource for the positions that Swedish critics take, and in those position-takings the foreign works are given their local meaning. Moreover, this local reproduction of literary works that have crossed the boundaries of their national origin depends on the place that both Swedish critics and U.S. authors have in a world literary space and not just on their bilateral relations.

Our focus in what follows is the Swedish reviewers' and critics' symbolic production of U.S. literature in Sweden. After a quantitative overview of the U.S. authors and genres that Swedish literary critics reviewed from 1980 to 2005, the long tail end of the essay will be devoted to a case study of how one author, Paul Auster, was ushered in by Swedish critics in the late 1980 s and early 1990 s, and particularly to how this author was appropriated differently by critics with different positions in the field.

American literature, like other foreign literatures with a large home market, is at the same time a marginal phenomenon in Sweden and yet a key cultural signifier in the Swedish field of literature. The full circle described by the itinerary from the Hemingwayesque prose cultivated by Thorsten Jonsson in the 1940s to the Carver-influenced short-story "boom" of the 1990 s reminds us of the way that particular U.S. authors have become as-

1 The author wishes to gratefully acknowledge the substantial contribution made by Alexander Ekelund in the research for this article. Thanks are due also to the Swedish Research Council for funding this research project and to the Sigtuna Foundation Archive for generous help.

2 I use the term advisedly, and bearing in mind Johan Svedjedal's valid point that one does not really study the reception of an author by studying reviews and criticism; the latter do, however, constitute one key link in the reception, and a study of these intermediaries is thus a reception study, even if it is not a study of the full reception. 
sets (and albatrosses) for young Swedish authors. There is also the broad impact of American bestsellers on the Swedish market, from Judith Krantz to Tom Clancy, such that the very idea of the bestseller is somehow American, despite the fact that such lists are, at the present moment, more or less entirely Swedish in character. Even so, as the business monthly Svensk Bokhandel notes, while the translation of foreign books is becoming an increasingly risky undertaking, everyone knows that the real blockbuster is almost by definition an international one, like the $\mathrm{Da}$ Vinci Code or the Harry Potter books (Roosvald).

But while in the large-scale field of consumption and the restricted field of production, the significance of American literature-and it is this term, rather than U.S. literature, that we must use in those contexts - is beyond dispute, what role does it play in the arena of practical criticism? Like all other forms of literature, American fiction in Sweden must be produced not only in its material form, as a printed, hard-cover novel, say, but has to be symbolically produced and reproduced. One of the chief agents in the symbolical production of literature is the critic. What concerns us here is what Edward Said has identified as "practical criticism," that is, the day-to-day reviewing activities, in contrast to the largely academic activities of literary history and extended interpretation, and to literary theory (3). ${ }^{3}$

As Donald Broady and Mikael Palme have argued, practical criticism in Sweden has largely been a kind of communication directed at other symbolic producers. In other words, it has constituted a field with some degree of autonomy, in Bourdieu's sense: the outcomes of struggles over critical value have been decided by the critics themselves rather than by external agents. However, the field may have become less autonomous in recent years, as Thomas Forser argues in his description of the "tabloidization of criticism" (Forser 1998). Insofar as it retains some autonomy, however, it involves critics taking up positions that are to be understood in relation to other critics, and by extension to positions in other fields, rather than as a platform for speaking directly to the readers of books. If we accept this description, any attempt to study the reception of foreign literary goods will have to involve some kind of mapping of the field of practical criticism, and a consideration of the relation between that field and other fields.

To map the subfield of practical criticism in Sweden in the past quarter 
century, then, we have sought to produce a sample of critics who could be argued to have had some impact on the field as a whole. In order to avoid working with a selection that was already selected, and thus mapping what we already think we know, we used two broad criteria to generate a population of significant critics: the critics selected have been prolific in the writing of articles about literature in general, or they have published in the important literary periodicals, or both.

We used the database Artikelsök [Article search] to locate articles (i.e. not reviews) on literature in Swedish periodicals and newspapers between 1980 and 2005. There are some problems with the Artikelsök database: its selection of newspapers has been reduced in two steps since 1980, from the original 50 to 30 in 1986, and from 2004 on, to only 15 daily newspapers. The selection of newspapers is based on library subscriptions. The same goes for periodicals, which means that some key literary periodicals have not been included among the 550 titles indexed, and it still remains for us to add critics that have been omitted because of this selection. ${ }^{5}$ Still, the $A r$ tikelsök coverage is very broad, and even the reduced number of newspapers means that articles written outside of the large cities of Stockholm, Gothenburg, and Malmö are included. The pattern is, furthermore, for critics who become prominent by their activities in any given small literary periodical to branch out and write for other literary journals as well as newspapers.

Our search turned up about 13,000 authors who wrote a total of almost 54,000 articles. We then reduced the 13,000 or so critics to 465 by including only those critics who had either published 30 literary articles or more in newspapers or more than four articles in periodicals specifically devoted to literature and culture. ${ }^{6}$ In addition, we included critics who had been particularly active in the first five years of the period, but whose total number of articles fell below the limit. Thus, when in the following we speak about "the critics" with no further specification, we refer to the selection of 465 critics who have published prolifically or strategically as outlined above. ${ }^{7}$ With this population established we then used Artikelsök, again, to

5 For example, neither the journal Kris, crucial for the generational shift in the 1980 s, nor $O E I$, with similar importance for a shift in the discussion of poetry in the past few years, have been indexed.

6 That is, the periodicals classified $\mathrm{G}$ or Bd in the Swedish library classification system.

7 Our sample of critics includes 159 women and 302 men. It is worth noting here that the mean number of reviews per female critic was 151 , for male critics 234 , if only to remind the reader that this is a field in which the distribution of authority is ordered by many different principles, one of them gender. 
list not just all articles by these critics, but also all the reviews. Again, there are limitations concerning the indexing, since, for example, Artikelsök does not normally include articles of fewer than 4,000 characters. In practice, however, reviews that fell below this limit were sometimes included on a case-by-case basis. ${ }^{8}$ On the whole, there is no reason to suspect that some systematic bias has distorted the selection. This search gave us a list of 94,955 book reviews by 465 critics. "Behold!" as Byron writes, "in various throngs the scribbling crew, / For notice eager, pass in long review."

How much space is given to U.S. authors in this collective judgment of what counts as literature in the contemporary arena? We will have to postpone exact answers to that question. At the end of the day-some other day-we will work with the full selection, but for our present purposes we made a further delimitation by looking only at authors who had enjoyed (or suffered?) ten reviews or more, which amounted to 2,164 authors out of 14,674 . What can be noted before turning to that selection, however, is that among the top 200 authors of the full sample, in terms of the number of reviews their books were given, 42 were non-Nordic writers, and of these, ten were from the US, seven from Britain, and three from South Africa. Eighteen other countries were represented by one or two authors.

Turning to the corpus of reviews about the 2,164 authors who garnered more than nine reviews for their books by our sample of Swedish critics in this period, we see in Table 1 the distribution among regions of origin of these authors.

It is obvious that the large majority of reviews are concerned with Swedish authors, and in our period the Swedish share has been very steady at around $69 \%$ annually. The overall proportions have been quite stable. Though U.S. authors had a slightly higher proportion in the first decade of our study than in the second, and then regained that level and surpassed it in the last six years, 2000-2005, these changes are modest. ${ }^{9}$

Taking the large view, then, Swedish newspapers and periodicals devote roughly $70 \%$ of its space to Swedish works, and 30\% to translated works. A rough comparison with the number of titles published in the period 1985 to 2000 , as presented in the Swedish branch organization's statistics, shows that the proportion of original Swedish titles, in the category of fiction,

8 Telephone interview with Eva Ingvarsson at Bibliotekstjänst, responsible for Artikelsök, 25 January 2008.

9 1980-89: $6.7 \% ; 1990-99: 6.2 \%$; and $2000-2005: 7.2 \%$. The only region that seems to have lost market share is Latin America: going from $1.6 \%$ to $1.3 \%$ and then to $0.9 \%$. 


\begin{tabular}{|lcc|}
\hline $\begin{array}{l}\text { National Origin of Author } \\
\text { of Text Under Review }\end{array}$ & $\begin{array}{c}\text { Total number } \\
\text { of Reviews }\end{array}$ & $\begin{array}{c}\text { Percentage } \\
\text { of Reviews }\end{array}$ \\
\hline Sweden & 37,266 & $69.4 \%$ \\
Western Europe & 5,607 & $10.4 \%$ \\
US & 3,537 & $6.6 \%$ \\
Eastern and Southern Europe & 2,567 & $4.8 \%$ \\
Rest of the world & 2,449 & $4.6 \%$ \\
Nordic countries & 2,243 & $4.2 \%$ \\
\hline Total & 53,669 & $100.0 \%$ \\
\hline
\end{tabular}

Table 1. Distribution of national origin of authors reviewed by our sample of prolific and/or prestigious critics between 1980 and 2005 .

fluctuates between $41 \%$ and $52 \% .{ }^{10}$ In terms of total printed volumes, the proportion is even lower. For whatever reasons, it is clearly the case that Swedish critics pay comparatively speaking more attention to Swedish works than to translated titles. American literature, like other non-Swedish literatures, is in that sense a marginal asset in the taking of positions, then. So, what makes it a resource that is also of key significance?

In The World Republic of Letters, Pascale Casanova has outlined the international relations of different national literatures that establish literary centers and peripheries, and the differential effects on writers depending on their location in that field of relations. Sweden occupies a particularly ambivalent position in that regard. It is no doubt a peripheral literary domain, or at least semi-peripheral, and as such its canonical figures are not strictly domestic. Working within the limits of a peripheral literature, Swedish writers tend to look to other nations' literary centers for principles of legitimation: Strindberg's attempt to make it in Paris may stand as a paradigmatic image for this relationship. ${ }^{11}$ Yet Sweden has considerable influence. The Swedish Academy decides what writers will be awarded the Nobel Prize, which has

10 Svenska förläggareföreningen, "Branschstatistik 2000." Pascale Casanova mentions the extremely high proportion of translations in the Swedish field, and finds part of the explanation for this in the effect of hosting the Nobel Prize (68).

11 See for example David Gedin, Fältets herrar, for an analysis of authorial strategies in the 1880 s, and see also Casanova about Strindberg and Paris. 
a real consecrating function globally. The peculiarity of a peripheral literary field with power over a central legitimizing function in world literary space makes it incumbent on Swedish critics to cultivate an orientation vis-à-vis other national literatures, and not only the dominant ones. All of this helps to explain the special importance in the Swedish field of criticism of that curious critical figure, the introduktör.

The word introduktör means "introducer" but when used in the context of literature in Sweden it has a particular aura. All national literary fields have functions like this, filled by the "cosmopolitan intermediaries" who are responsible for moving texts across national borders, ${ }^{12}$ but in each national context, this function has its own particular history. In Sweden, you can introduce a great many things without becoming an introduktör, and with only a slight exaggeration the job description is such that there may have existed only one proper holder of this office, the poet, critic, and member of the Swedish Academy Artur Lundkvist. As the New York Times obituary noted, he "introduced Swedish readers to many writers," and the brief article then lists four Nobel Prize winners as examples, without belaboring the point. Lundkvist's exemplary career covered a broad range of writing, but the role of introduktör is primarily that of a critic who discovers foreign authors before they become generally recognized, as Lundkvist did especially with Latin American writers, such as Gabriel Garc'a Márquez, Jorge Amado and Pablo Neruda, but also North American writers like John Dos Passos and William Carlos Williams. ${ }^{13}$ The role may also include translation of these authors. The only other Swedish critic who has filled this role in a comparable way is Anders Österling, ${ }^{14}$ but there are introduktörer on

12 See Casanova, $20 \mathrm{ff}$.

13 Artur Lundkvist discussed American authors in three books, Tre amerikaner (1939), Amerikas nya författare (1940), and Diktare och avslöjare i Amerikas moderna litteratur (1942). See René Vásquez D'az' Oliktänkaren: en bok om Artur Lundkvist (Ordfront, 2006) for a comprehensive presentation of Lundkvist.

14 Per Rydén claims in passing that Österling is almost the preeminent introduktör of foreign literature (79) and later qualifies this by noting that he is "one of the three great introducers of foreign literature in the Swedish literary criticism of the past one hundred years" (275, my translation), the others being Carl David af Wirsén and Artur Lundkvist. He moves immediately from this observation to their role in "the most recognized institutionalization of the Swedish view of world literature, the selection of Nobel prize laureates" (my translation 275). See Forser's assessment of Lundkvist's practice as introduktör, which for Forser makes him less of a real critic than the "four big ones," Böök, Vennberg, Lagercrantz, and Holmqvist (Forser, Kritik av kritiken). These names are all part of the established narrative of Swedish criticism, and it may very well be one that needs revising, but the exemplariness of Artur Lundkvist's role in this narrative forms a useful reminder of the particular stakes involved in the introduction of foreign literature into the Swedish field. I am grateful to Marta Ronne for cautioning me against uncritically accepting this narrative. 
a more modest scale, such as Heidi von Born and Per Wästberg, and, continuing Wästberg's mission of introducing African literature, Stefan Helgesson. ${ }^{15}$ It is significant that the deliberate task of introducing authorships from the periphery has been taken on by a literary journal named after a periodical briefly edited by Artur Lundkvist, Karavan. ${ }^{16}$ The prestige that comes with successfully bringing in new authors-provided that further symbolic production strengthens those authorships - is no doubt a scarce type of distinction, and it is difficult to imagine a major Swedish critic who displays no introductory activities.

On the other hand, this particular function of the Swedish critic is important for giving a local meaning to the works of individual foreign writers. As Rolf Lundén has pointed out, there is little doubt that

individual Swedish critics play an important role in determining whether an author will make it into the [Swedish] canon. The significance of critics like Lundkvist, Jonsson, and Erik Lindegren should not be underestimated; the same is true of Gierow's actions to launch O'Neill as a playwright. One explanation as to why certain writers such as Crane and Fitzgerald have been neglected in Sweden may certainly be that they found no critics ready to champion their cause. (142)

The task for a study of the conditions for transnational movements of literary works is in part simply to see which critics are there to "champion the cause" of particular writers. On that task follows the one of analyzing the habitual orientation of those critics.

It is worth remembering that the books that Swedish critics review are to a great extent the books that have been chosen for translation by Swedish publishers. Reviews in Swedish newspapers and periodicals, as elsewhere, are concerned almost without exception with books recently made available on the Swedish book market. Such is almost by definition the case with practical criticism. A study of the selection made by reviewers (and newspaper editors) - the books that were reviewed-from the available material - the books that were published-remains to be done for this period. However, the figures we do have, which will be presented in the following, show which newly available American authors the prolific and/ or prestigious Swedish critics have focused on in this period, with the ca-

15 Tomas Forser sees Wästberg, typically, as having done for African literature what Lundkvist did for Latin American literature (Kritik av kritiken, 191).

$16 \mathrm{http}: / /$ www.karavan.se/html/kultur.html 
veat that they may have done so under conditions not entirely of their own choosing. Newness here refers to the Swedish-language book market: we have included only authors who had had no translations into Swedish published before $1980 .{ }^{17}$

The American authors, who had their first translations into Swedish published in this period, and who were reviewed ten or more times by the sample of critics between 1980 and 2005, numbered 54 individuals. The works of these authors elicited 1140 reviews by our sample of critics.

Of the authors who earned this measure of recognition, twenty can be labeled genre writers. To relegate an author to "genre" status is bound to invite controversy, and in five or six cases my choice could be challenged on various grounds. While the crime writers are the least likely to raise many quibbles, there have always been more or less successful bids to confer a different status on certain crime writers, and among the current crop James Ellroy and Walter Mosley may be touted as new Raymond Chandlers or Dashiell Hammetts. As we will see, they are, in critical practice, granted a different treatment than their fellow crime-writers. Dan Brown writes a kind of suspense thriller ${ }^{18}$ and Stephen King, for all his versatility, is mainly a horror writer, while Jean M. Auel can be said to have created a genre of her own, the Paleolithic Romance. Finally, there is just one science-fiction author in this selection, William Gibson, and his peculiar status makes any classification difficult. One could argue that he is Canadian and thus get rid of the problem, but Gibson's literary career, like Douglas Couplands, is U.S.-based: they published their books with New York publishers from the beginning; Gibson, moreover, was born in the US.

In terms of critical attention, there is a somewhat blurry and yet decisive demarcation line between the genre and the non-genre writers. Examining the ratio between the number of reviews and the number of titles translated into Swedish, we see that nineteen of twenty-two genre writers had fewer

17 The use of this criterion results in the inclusion of a writer like Tillie Olsen, who belongs to an earlier generation of writers in the US context but becomes available in translation only with the translation of Tell Me a Riddle in,, 1980 (as Ge mig en gåta).

18 In an article in Dagens Nyheter, Lena Jordebo notes that the Swedish publisher calls the book a "novel of suspense" but could just as well have called it an adventure mystery or a conspiracy thriller ["Det svenska förlaget kallar "Da Vinci-koden" av Dan Brown för en spänningsroman, men det kunde lika gärna ha stått äventyrsdeckare eller konspirationsthriller på omslaget."]. She also notes that popular literature is not taken as seriously in Europe as in the U.S., and thus takes the U.S. debates about the book as a symptom of the American lack of concern with these distinctions. 
than three reviews per translated title, while twenty-six - all but six - of the non-genre writers had more than three. ${ }^{19}$ The three cross-over authors who managed to sneak out from under the genre shadow were Dan Brown, Walter Mosley, and James Ellroy. Clearly, in the case of Brown, it is the absolutely phenomenal success of The Da Vinci Code that has prompted reviewers to consider his work, often in quite condescending terms, ${ }^{20}$ while Mosley and Ellroy represent that peculiar American species, the hard-boiled, stylistically distinct urban crime writer. Whatever the merits of these writers, the ratio between review attention and published titles makes clear that their work becomes available for critics' position-takings only under particular conditions. As a general rule, writers who work within popular genres are always riskier to deal with and thus a less likely vehicle for establishing the introduktör role. With that observation, we will leave the genre writers for another time.

Table 2 lists the non-genre writers who were selected for a high measure of attention by the Swedish critics. In terms of sheer quantitative attention, Paul Auster is clearly our man, with more than twice as many reviews as the next writer on the list, Jayne Anne Phillips. However, this is to some extent an effect of the great number of Auster titles that have been translated into Swedish, with almost every book publication in the original language having been given a Swedish-language version. ${ }^{21}$ If we were to compensate for this effect, and sort the list after the ratio of reviews to translated titles, Edmund White would be at the top, with his one translated title, En pojkes egen historia, (A Boy's Own Story) being very widely reviewed. On the other hand, no Swedish publisher has found this one-time critical interest sufficient justification for translating other books by White. Where publishers have been motivated to translate entire oeuvres of fiction (and I include also memoirs and essay collections), the authors' total production has typically been restricted to two or three books, with the outstanding exception, in this respect, of Bret Easton Ellis, all of whose six novels have been translated.

19 The non-genre titles received an average of 4.7 reviews per translated title, while the genre books only had 2.1 .

20 Dagens Nyheter did not favor The Da Vinci Code with a review, but Svenska Dagbladet's Carl Malmberg did, with some jokes at the author's expense ["his idea of erudition makes you think of American high school essays or some guide book titled 'Europe on seven days"' (my translation)].

21 At this point, we have no way of determining whether critical attention to any degree affects publishers' choices. It seems likely that Auster's success in Sweden depends on a large number of factors, from which practical criticism cannot be excluded. 


\begin{tabular}{|c|c|c|c|c|}
\hline Author & $\begin{array}{c}\text { Number of } \\
\text { reviews }\end{array}$ & $\begin{array}{l}\text { Number of } \\
\text { reviews per } \\
\text { translated title }\end{array}$ & $\begin{array}{c}\text { Titles translated } \\
\text { into } \\
\text { Swvedish }\end{array}$ & $\begin{array}{c}\text { Proportion of } \\
\text { translated } \\
\text { titles }\end{array}$ \\
\hline Auster, Paul & 95 & 5.3 & 18 & $90.0 \%$ \\
\hline Phillips, Jayne Anne & 40 & 8.0 & 5 & $55.6 \%$ \\
\hline Wolff, Tobias & 38 & 6.3 & 6 & $66.7 \%$ \\
\hline DeLillo, Don & 38 & 5.4 & 7 & $46.7 \%$ \\
\hline Kennedy, William & 35 & 5.0 & 7 & $63.6 \%$ \\
\hline Carver, Raymond & 27 & 6.8 & 4 & $36.4 \%$ \\
\hline Shields, Carol & 27 & 4.5 & 6 & $35.3 \%$ \\
\hline Ellis, Bret Easton & 25 & 4.2 & 6 & $100.0 \%$ \\
\hline Ozick, Cynthia & 24 & 8.0 & 3 & $30.0 \%$ \\
\hline McCarthy, Cormac & 22 & 5.5 & 4 & $33.3 \%$ \\
\hline McInerney, Jay & 22 & 4.4 & 5 & $83.3 \%$ \\
\hline Walker, Alice & 20 & 4.0 & 5 & $38.5 \%$ \\
\hline Hustvedt, Siri & 19 & 6.3 & 3 & $100.0 \%$ \\
\hline Olsen, Tillie & 18 & 6.0 & 3 & $100.0 \%$ \\
\hline Salter, James & 17 & 4.3 & 4 & $40.0 \%$ \\
\hline Proulx, E. Annie & 16 & 2.7 & 6 & $75.0 \%$ \\
\hline Coupland, Douglas & 16 & 1.8 & 9 & $81.8 \%$ \\
\hline McCourt, Frank & 14 & 4.7 & 3 & $100.0 \%$ \\
\hline Guterson, David & 14 & 4.7 & 3 & $75.0 \%$ \\
\hline Cunningham, Michael & 14 & 3.5 & 4 & $80.0 \%$ \\
\hline Toole, John Kennedy & 12 & 6.0 & 2 & $100.0 \%$ \\
\hline White, Edmund & 11 & 11.0 & 1 & $14.3 \%$ \\
\hline Franzen, Jonathan & 11 & 3.7 & 3 & $75.0 \%$ \\
\hline Chabon, Michael & 11 & 2.8 & 4 & $66.7 \%$ \\
\hline Piercy, Marge & 11 & 2.2 & 5 & $29.4 \%$ \\
\hline Erdrich, Louise & 11 & 1.4 & 8 & $66.7 \%$ \\
\hline Tartt, Donna & 10 & 5.0 & 2 & $100.0 \%$ \\
\hline Thompson, Hunter S. & 10 & 5.0 & 2 & $14.3 \%$ \\
\hline Dickinson, Charles & 10 & 3.3 & 3 & $50.0 \%$ \\
\hline Gilchrist, Ellen & 10 & 3.3 & 3 & $15.0 \%$ \\
\hline Acker, Kathy & 10 & 3.3 & 3 & $13.6 \%$ \\
\hline Harrison, Jim & 10 & 2.5 & 4 & $28.6 \%$ \\
\hline
\end{tabular}

Table 2. Non-genre American authors who received ten or more reviews by the sample of prolific and/or prestigious critics in Sweden between 1980 and 2005. 
His Brat Pack fellow Jay McInerney and Generation X peer Douglas Coupland, too, show a high rating. The meaning of these numbers is ambiguous, but they point out directions for further investigation. Auster's unique position in terms of the total number of reviews, Jayne Anne Phillips's and Cynthia Ozick's high batting average, the Generation X authors' favor with publishers and reviewers - all of these need to be analyzed in terms of their meaning within the field of criticism. The present occasion leaves us space to pursue only one of those leads, and it seems justified to look at American postmodernism as a particularly interesting case.

In the field of criticism, the labels and categories applied to literature are of prime importance. If we consider the list of writers in the light of the categories that have been operative in American criticism, we can discern three groups. First of all, Paul Auster and Don DeLillo, first and fourth name on the list, represent the second wave of American postmodernist writing, and as we will see they are quite significant in that capacity. Second, we find writers who have variously been labeled "dirty realists" or "minimalists" or just new realists, including Jayne Anne Phillips, Tobias Wolff and Raymond Carver. Bret Easton Ellis and Jay McInerney have been lumped together as writers of a "blank generation" or "Generation X" along with Douglas Coupland, or as the Brat Pack, along with Tama Janowitz (who only received four reviews for the two novels that have been translated into Swedish). The relatively high recognition granted to representatives of these well-promoted "movements" is not surprising, if we assume precisely that Swedish critics operate with categories that are taken over from the American context of legitimation. As representatives of new trends in American writing, the authors would constitute valuable goods, and for the critic who can "introduce" them properly, there would be substantial symbolic profits.

We need to remind ourselves of two things before we take that insight further. First, we are dealing with practical criticism that works with what the publishers make available, but, second, we are looking at the attention paid to American writers by a sample of the most prolific and/or strategically published Swedish reviewers. Our main focus here is on what is distinctive in the practices of "introduction" carried out by the Swedish critics. It is important to show that there is something distinctive about the Swedish reception compared to the original context of recognition, and also to show that this distinction is at least to some extent not only a reflection of Swedish publishers' decisions. 
Is the pattern of recognition in our material different from the recognition afforded the authors in their original context? For a rigorous comparison with the original reception of these authors, it might appear that we would need a mapping of the original U.S. reviews, but further reflection tells us that this is perhaps not quite so. The Swedish translation normally lags behind the first reception and the defining moments of early recognition (the average time lag between publication of the first book of fiction, or memoir, in the U.S. and publication of the first Swedish translation is almost nine years for this sample of writers, the median is six years) so that Swedish reviewers normally have recourse both to an accumulated body of practical criticism and to the extended discussion that is found in quarterlies and in strictly academic work. Swedish practical criticism of American literature is therefore almost without exception a symbolic elaboration of the original symbolic production, and, as we shall see, of other secondary symbolic reproduction instances. However, it is not a sheer transmission, as is clear if we simply compare the results in Table 2 with a list which ranks the same authors according to the number of articles listed in the MLA International Bibliography for each of them. ${ }^{22}$ If the Swedish reception mirrored the general recognition accorded to these authors as measured by the number of American scholarly publications, the ranking would be roughly the same, but in fact there are a number of major discrepancies. Kathy Acker is one of them. No doubt her work has had a much higher degree of academic recognition than general market impact, and there have only been three translations available for Swedish critics to work with, but perhaps it is still worth asking why those three books have been given so little coverage. ${ }^{23}$ What also needs to be explained is the poor performance of Louise Erdrich, a Native-American writer who enjoys high academic recognition in the US, and has had a higher proportion of her works translated than the average,

22 Scholarly articles listed in the MLA International Bibliography have the virtue of being an easily accessible basis of comparison. I am aware that it is a partial measure of recognition, but the journals and periodicals indexed by the MLA range from highly academic quarterlies to periodicals with a fairly wide circulation, and there is little doubt that the kind of academic recognition we can measure in this way corresponds to a more general critical recognition. The procedure was as follows: using the on-line database, each author's name was introduced in a search for "Persons, about" with the following limitations: publication date between 1979 and the end of 2005, articles in English only. I made sure that the entries were about the author in question. For example, a search for Charles Dickinson yielded eight articles, which all were about Emily Dickinson, but also included one person named Charles. For "Dickinson, Charles," there were no hits.

23 Acker has the lowest proportion of translations of all the authors covered here. 
but has the lowest review coverage of all the non-genre writers. Similarly, African-American author Alice Walker is at the top of the list of MLA entries, but comes a middling thirteen in the list of Swedish review attention. By contrast, the way Swedish critics have taken to the "dirty realists" Tobias Wolff and Jayne Anne Phillips and the postmodernist Siri Hustvedt raises other questions. ${ }^{24}$ Paul Auster and Don DeLillo were both among the top ten authors in terms of general scholarly recognition, but their places were reversed in comparison with the Swedish reception: there were 388 articles published about Don DeLillo between 1979 and 2006, while Auster's work had generated only 148 articles. As we have noted, Auster's position in terms of quantitative reception is remarkable, while these two postmodernists have almost exactly the same number of reviews per translated title. The introduction of Auster and DeLillo demonstrates that the Swedish reception does differ from the symbolic production in the original context. For a consideration of specific critical strategies, the rest of this article will look closer at the confirmation of the "postmodern breakthrough" as it was embodied by Auster in the field of Swedish criticism in the late 1980s.

Before we look at Auster it must be noted that he and DeLillo belong to the second generation, or possibly even third generation, of American postmodernist authors. The American writers who first were mustered to define postmodernism in literature were not well served by Swedish publishers. There is not a single translation of any of John Barth's many works, Robert Coover's minor novella Spanking the Maid (Att smiska hembiträdet) is the only work of his available in Swedish (and that was not until 2007), and a similar strategy of representing an author with a short but typical piece is found in the examples of William Gass's novella "In the Heart of the Heart of the Country" (I hjärtat av hjärtat av landet) and William Gaddis's relatively short Carpenters Gothic (Träslott, 1987). After an early translation of The Crying of Lot 49 (Buden på nummer 49, 1967), Thomas Pynchon's major work, Gravity's Rainbow, did not appear in Swedish until 1996 (Gravitationens regnbåge). As Lundén has argued, "in a small coun-

24 It is hardly entirely coincidental that Hustvedt has Norwegian parents and is married to Paul Auster. Jayne Anne Phillips' early reception was partly the effect of a promotional interview tour, so that the first published translation was reviewed in tandem with interviews conducted in various Swedish cities. Significantly, one of the auspicious reviews was written by Artur Lundkvist, "Flicka med framtid," [Girl with a future!] in 1981. In it, Lundkvist is moved by the case of Phillips to reflect on "the caprice of market promotions and success." 
try such as Sweden these difficult texts would find few readers, those interested in Postmodernism are often highly educated and would prefer to read the texts in the original, and Sweden has no tradition of intellectualism that would favor such sophisticated metatexts" (140). One should add, also, that the new intellectualism of the 1980s preferred to go to the continent for its sophistication, and we might speculate that American sophistication is not a comfortable trope for Swedish criticism. The case of Auster helps us make that point.

As far as the records can tell, there is no critical introduction of Auster before the first Swedish translation in the fall of 1988, Stad av glas, (City of Glass, the first volume of the New York trilogy). This slim volume was reviewed by a number of provincial newspapers and by Lars-Åke Augustsson in Expressen and Karl Steinick in Göteborgs-Tidningen in late October 1988. Augustsson takes the translation as the occasion for discussing Auster's works thus far, referring to the recently published (in the U.S., that is) In the Country of Last Things. Most importantly, he names Auster "the perfect author for the eighties" and draws straight lines of kinship to Kafka and Borges, in the process removing Auster from the specific American situation. The New York trilogy, he says, is about more than a metropolis, or a continent, it is about a world.

From that review onwards, the name of Kafka becomes an inseparable reference, as can be seen just from the captions of early reviews and presentations: "Paul Auster-a Kafka in New York" (twice! Sjöblom 1990, Vogel 1990), "An American Kafka" (Svensson 1991), "the Kafka of our time" (twice! Andersson 1989, Nordensson 1991) "An American Kafka who affirms silence” (Gedin 1991), “A modern Kafka,” (Schueler 1989), “A modern Kafka in Brooklyn" (Vogel 1998). This association with the most iconic of European modernist masters is ubiquitous and reinforced, no doubt, by Auster himself, who has never made a secret of his admiration of a handful of European masters - Beckett, Kafka, Blanchot, Jabés - along with Borges. ${ }^{25}$ But the choice of Kafka's name in the headlines (no matter if we assume that this is more the choice of editors than of the critics themselves) reflects the logic by which Kafka has enjoyed an "extraterritoriality" which

25 See Auster's admission of the impact of Kafka and Beckett in The Art of Hunger (257) where he also writes about Blanchot and Jabés, both of whom he translated. See also the overview of Auster criticism by Patricia Merivale. Note that these influences can be used in various ways by a critic, as in Gary Indiana's notorious review of Moon Palace which saw in Auster "a mechanical engineer impersonating Kafka and Beckett." 
makes him stand for a purely literary significance: an American Kafka is also a de-Americanized Kafka. ${ }^{26}$

Three critics give substantial portrayals of Auster before the entire trilogy is out on the Swedish market: Git Andersson, Kaj Schueler, and David Gedin. Gedin was just entering the field of criticism at this time, and did so with a five-article series on "New Americans" in Sydsvenska Dagbladet, of which the Auster portrait was one. Git Andersson was active for only a couple of years, mostly writing for provincial newspapers, where she wrote about Paul Auster, Kathy Acker, Tama Janowitz and Ed McBain. Schueler has written reviews and articles for Svenska Dagbladet, mostly, but he also wrote for literary journals and for a short spell contributed to Dagens Nyheter. Neither Schueler nor Andersson would make further investments in Auster, however, and Gedin, who wrote several reviews of subsequent Auster novels, would move into academic work, largely relinquishing practical criticism, after the early nineties.

Instead, the critics who picked up and carried Auster's unfolding oeuvre as part of their critical keepsakes was Mikael van Reis in Göteborg-posten and, more than anyone else, Mats Gellerfelt in Svenska Dagbladet. ${ }^{27}$ While the number of reviews is not important in itself, the decision to follow a career, to become a kind of local guardian for a foreign writer, implies an affiliation that goes beyond the strictly professional task of reviewing books as they come out. Insofar as a critic is in a position to choose the books he or she will review, the affiliation is also a manner of declaring one's standards. Such standards are also declared by means of early positions taken regarding an author.

Gellerfelt gave the three volumes of the "New York Trilogy" a major review in $S v D$ on March 16, 1990, and in 1993 he published a review article with reference to the Swedish translation of In the Country of Last Things. We will take Gellerfelt's introductory criticism of Auster as one key instance of how this American author was appropriated in the Swedish context. To provide a revealing contrast to Gellerfelt's use of Auster, and to help us see how Paul Auster served as a key symbolic resource for a strug-

26 On this extraterritoriality and the value of having universality as a major aspect of the symbolic production of the author, see Casanova, Chapter 4, and especially 155-56.

27 Gellerfelt has reviewed ten Auster titles and van Reis nine, but counting individual review items they have eight and seven, respectively. Both have followed Auster's career for a long time, fourteen and fifteen years. 
gle over values among Swedish critics, we will look closely at another instance of early, introductory, criticism of Auster: the articles written by Aris Fioretos, one published in Artes in early 1990 and one in 90tal in 1993.

To begin with Gellerfelt, we have a solid account of his entry into the critical field in Donald Broady's and Mikael Palme's "Inträdet" ("The entry"), in which Gellerfelt's establishment as a major Svenska Dagbladet critic is seen as part of the re-drawing of boundaries around what was then promoted as properly literary issues, and thus as a rejection of the dissolution of those boundaries in the political and socially conscious criticism of the late sixties and seventies. Gellerfelt's critical task was then to establish a hierarchy of values in which the selective tradition of high modernism defined what was of literary value. What is of particular significance for my discussion here is the renewed importance of international literary norms when these "modernist" values were hailed. As Broady and Palme observe, "[t]he early 1980s was a period when it appeared increasingly impossible to argue for an author's qualities by pointing to his Swedishness, to a local embeddedness, a position on the side of the international highways" (180). However, the next phase of this return to properly literary values was supervised by a group of critics who were far more versed than was Gellerfelt in the latest developments in primarily French critical discourse, a group Broady and Palme call "the men of '82" - led by Horace Engdahl and Anders Olsson, now both members of the Swedish Academy. It is not important to rehearse Broady's and Palme's account of the "poststructuralism debate," but it is necessary to think about the reception of American authors in terms of an unstable equilibrium, involving different generations, between the mainstream of practical criticism that still dominated the culture sections of the daily newspapers ${ }^{28}$ the new "academic" and theoretical criticism represented by the successive editorial boards of the periodical Kris, and the forces of tabloidization.

Mats Gellerfelt is, by any account, one of the leading practical critics of this period, with 1,119 reviews published, 1,030 of them in $S v D$, and 158 critical articles, most of them in $S v D$, but also a dozen in Månadsjournalen and Metallarbetaren in the $1980 \mathrm{~s}$ - the former a richly illustrated monthly with a broad, general readership, the latter the periodical published by the

28 As Forser notes, the Swedish format of the kultursidorna [...] the culture pages of a daily newspaper [...] was established in the late 1970s, and in the late 1990s they were being dissolved into an uneasy mixture of entertainment news and traditional criticism. 
metal workers' union. He also published a modest number of articles in Moderna Tider and Parnass in the 1990s, both of them with a distinctly more intellectual cast, the latter representing the umbrella organization for literary societies in Sweden. If we look at the national origins of the authors whom Gellerfelt reviewed, we find an emphatic confirmation of his international outlook: just under $50 \%$ of his reviews are about Swedish authors (the average, we recall, was almost $70 \%$ ) and $18 \%$ referred to U.S. authors (contrasted with the overall average of $6.6 \%$ ), which places the U.S. on a par with Europe in Gellerfelt's universe of critical reference. The U.S. authors he favored belonged to the broad mainstream of American realism. Not surprisingly, Joyce Carol Oates has the largest number of reviews (how could it be otherwise?), but generally Gellerfelt reviews mainly male writers: Richard Ford, William Kennedy, Joseph Heller, James Salter, Tobias Wolff. Paul Auster, in this company, is the odd man out. What is otherwise striking about Gellerfelt's American profile are the many crime writers - 19 of his 104 reviews of U.S. writers are about crime novels - but then this is part of Gellerfelt's agenda: to move between high and low, where low is particularly represented by more or less hard-boiled crime writers. This preference also extends to his activities as a translator: between 1995 and 1999 Gellerfelt translated five of Walter Mosley's "Easy Rawlins" novels. A similar move between respected and popular genres can be seen in his own writings, which include a poetry collection and a novel, but also a biography of the leader of the Swedish Christian Democrat Party and a "how-to" book for bachelors.

Turning to Aris Fioretos, we find a series of choices that contrast with Gellerfelt's populist postmodernism. Fioretos is not as prolific a reviewer as Gellerfelt, and we count only 115 reviews. After writing practical criticism mostly for the evening paper Expressen in the late nineties and the first years of the new century, Fioretos moved over to Dagens Nyheter in 2005 , a move which confirms the logic by which the dominant newspaper recognizes those with the disposition to take the most distinctive positions. Of his 37 articles in this period, almost all were published in respected literary periodicals, such as Artes, BLM, Aiolos, Tidskrift för litteraturvetenskap, Lyrikvännen, and 90tal. As part of the second generation of editors at Kris, Fioretos helped sustain the theoretically informed critical revolution associated with that journal. Fioretos also published literary books, but his chosen genres are the less conventional ones of prose poems, essays, and short shorts, prompting a critic to claim that they are unlike anything else in 
the Swedish flow of books, "free-floating sui generis textual worlds." 29 The probability that Fioretos would write a conventional biography of the leader of a political party is, in other words, near zero. Where Gellerfelt translated hard-boiled crime stories, Fioretos interpreted poetry by Paul Celan, Friedrich Hölderlin, and Paul Auster, and translated three of Vladimir Nabokov's fictions, and also two books by Auster. It is telling that Fioretos chose to translate the two titles of Auster's that least conform to any genre requirements, The Invention of Solitude and The Red Note-book. Fioretos approaches Auster as an ally in a literary project rather than as a writer of books for a market.

By bringing Fioretos and Gellerfelt into contact, I am, up to a point, repeating the story told by Broady and Palme, in which Gellerfelt's initial break with the critical tradition of the sixties and seventies was itself outflanked and put in its place by the "men of 1982," the editors of Kris who became critics at Dagens Nyheter and then went on to their seats in the Swedish Academy. The appropriation of Auster by Gellerfelt and Fioretos represents a continuation of that story with the added plot element of the American author. Auster becomes available for these critics on terms decided by a fundamental polarity between two ways of relating to postmodernism, both of which are relatively independent of how Auster was first established in U.S. criticism. Furthermore, Auster is placed differently by the two critics, as we shall see.

Postmodernism in Sweden became one of the issues in the challenge raised by a new generation of critics against the generation which had been dominant throughout the 1970s. In two debates in the 1980s, the system of relations between critics was reorganized around the new positions taken by young critics. The first one, the so-called "poststructuralism debate" took place in 1982, and has been analyzed by Broady and Palme; the second one, initiated by the art critic Lars O Ericsson in 1987, was more exclusively concerned with art. What is obvious in hindsight is how both debates start with the advent of a young critic at Dagens Nyheter. But the conditions that enabled the successful debates need not detain us here. The point is that the particular American authorship we are looking at was delivered as a symbolic product demanding some kind of response at a time when the postmodern breakthrough had taken place, but had not yet 
been consolidated into a relatively fixed set of ideas in the Swedish field of criticism.

Gellerfelt's review, in Svenska Dagbladet, 16 March 1990, of the three volumes of the New York trilogy bears the marks of this situation. First, he carefully questions the newness of the "post" when he explains that Auster "works in a well known modernist tradition which we tend to call postmodernist these days." ${ }^{30}$ This diminishment of the importance of the postmodern is continued when Gellerfelt points to the most characteristic postmodern features in Auster's book as signs of comparative weakness: "perhaps one might say," says Gellerfelt, "that Auster is just a bit too typical in his system of references," but he is saved by his "skill" without which "one might possibly think he is too trendy for his own good (but the kind of literature he writes would appear to have diminished in importance in the last few years)." Moreover, Gellerfelt points out that what is really original in this tradition is something that "the great masters of modernism-Joyce, Pound, and Eliot - already understood." The final verdict, that Auster "already appears as one of the most interesting new writers in the U.S.," is based firmly on the insights of the trilogy into the "entirely realistic lives that people today actually lead in the anonymous mass cities." This peculiar emphasis on realistic lives that are actually lived emphasizes the primacy of everyday human existence as a core value for literature, and the subservience of literature as a vehicle for describing it.

The reality that Fioretos finds in Auster's work is of a different kind. It lies in a relationship between corporeality and textuality which is, Fioretos notes, different from the "aestheticization of reduction" found in literary modernism, since the body, with its hunger, remains real in Auster's poetry and in the narratives that Auster has written about, Kafka's "The Hunger Artist" and Hamsun's Hunger. ${ }^{31}$ Having carefully distinguished Auster's type of reduction from high modernism, Fioretos attaches it to a series of authors who are allowed to remain untainted by reductive labels: Samuel Beckett, Osip Mandelstam, Paul Celan, André de Bouchet, Jacques Dupin, Wallace Stevens, Stéphane Mallarmé and Maurice Blanchot. ${ }^{32}$ Fioretos's principle for which authors are included and associated

30 This quote and the following ones are my translations.

31 Aris Fioretos, "Ordens hunger," 22. This quote and the following are my translations.

32 This list of authors is collocated from "Ordens hunger" and from "Konsten att leva: Om Paul Auster." [The art of living: About Paul Auster]. 
together remains implicit, part of a contract between knowing author and reader. Partly, the great difference between Fioretos's and Gellerfelt's analyses of Auster lies in the genre and site of publication, since Fioretos introduces Auster in two literary journals, accompanied by poems and a "prose poetry speculation" by Auster, translated by Fioretos. But of course that difference is part of what defines a critical practice, and the range of practical criticism.

We could go further into specifying the differences between the trajectories taken by Gellerfelt and Fioretos, and the way their position-takings reflect those itineraries, but the point at present is to see how the American author becomes available for an elaboration that is necessarily a product of those differences. In other words, the local meaning given to Auster's work in the critical discourse takes the form of affirmations and rejections of already existing associations that attach to Auster's work and its symbolic reproduction, and these positive or negative elaborations are determined by the positions of the critics. The particular emphases in these local articulations could be studied by looking at any of the early critical appropriations of Auster, but I have chosen to isolate just two, clearly contrasting strategies. As is almost always the case, the key differences are found not so much in the substance of what is claimed, but in how the claims are made. Both Gellerfelt and Fioretos include the inevitable reference to Kafka, but in Gellerfelt's account this is stated as a rather blunt resemblance- "an author that Auster resembles"-as part of the claim that New York is "our equivalent" of Prague, while Fioretos goes to a collection of Auster's essays to distil the essence of Auster's kinship with Kafka in a strictly autonomous search for the relationship between words and the corporeal needs they can possibly speak of. And of course the references that Fioretos add are considerably more esoteric than the familiar names that Gellerfelt mentions as being somewhat too typical.

The two Austers reproduced by these two critics correspond to their general profile as "introducers"-Gellerfelt's Auster is more American, as it were, and this is especially clear if we see Auster's interest in the hardboiled detective story as something that corresponds to this Swedish critic's interest in old and new practitioners of that genre. On the other hand, Fioretos's poet-novelist is defined by his recognition of French poetry and his kinship with a Kafka and a Hamsun who remain European even as they transcend their particular locations. It is quite fitting that Fioretos, when his first introductory article is published, was teaching at the Department of 
German at Johns Hopkins University. The itinerary of the academic whose investments in Continental theory were made partly at Yale University allows Fioretos to claim Auster as a writer who is as much French as American, but who is, above all, not bound by any national limits.

From the point of view of an American critic in the U.S., in fact, Paul Auster could be seen as a "European writer," as Adam Begley noted in his review article of Leviathan.

In this country [the U.S.], the 45-year-old Auster remains a cult figure, his name familiar to devotees of literary fiction but otherwise little known. Not so in Europe, where he has become a celebrity, his success nothing short of remarkable. [...] In the French press he is hailed as a leading American writer. In Germany he is recognized on the street; taxi drivers ask for his autograph. [...] The usual way to explain Auster's success abroad is to say that his novels belong to a European tradition [...].

This European tradition is paramount in Fioretos's introduction of Auster, which thus follows up on the recognition accorded to the New York Trilogy in France, from the moment the first part of the trilogy was published by Actes Sud in 1987. It is not incidental that French recognition enters my account here. To locate the place of Auster in the field of Swedish literary criticism is to be forced to take in that "world literary space" which Casanova has begun mapping. The meaning of Paul Auster's work in Sweden is not a matter of a simple translation of an American text into a Swedish context, but brings into play multiple, international forces. The Auster read and translated by Fioretos is Auster as read at Yale or in Paris, while the Auster that Gellerfelt reads is one whose real feelings for actual people living in New York, a real American city, can be seen to transcend the academic games and postmodern references so as to speak of America directly to Swedish readers. Fioretos, on the other hand, is granting Auster's work the literary autonomy that makes it immediately part of a transnational corpus of writing.

To what end, you may ask, these two caricatures? A populist Americanism represented by a critic with a working-class background whose travels in America by-passed Yale and Johns Hopkins in favor of the Grand Ole Opry. ${ }^{33}$ On the other hand, an esoteric un-American cultivation of the literature of silence and emptiness, represented by a nomadic academic, the son

33 Per Mortensen. "Han laddar med egen kanon." This is a portrait of Mats Gellerfelt on the occasion of his fifty-fifth birthday. 
of a medical professor and a gallery owner, who came to Yale after having attended Derrida's seminars in Paris. ${ }^{34}$ The caricature is a form that helps bring out differences, since it exaggerates distinctive traits, and by overstating the distance between these two symbolic reproductions of Auster on Swedish ground, the caricatures insist on the effects of such distances within a field. It also opens our eyes to the particular distances covered by the individual critic on his or her way to the place of the critical verdict. That Fioretos came to the U.S. by way of Paris, and then took both these symbolic sites back to Sweden, traces a route that makes a curious kind of sense in terms of Auster's return to his own writing by way of living in Paris and translating French poetry.

Perhaps Paul Auster's preeminent place among contemporary U.S. authors in the Swedish literary field has something to do with the possibility that he is not so much an American author as a European one with a U.S. passport. It is in the name of a particular, selective tradition of literariness, rather than Americanness, that Fioretos can welcome Auster's writing, while Gellerfelt adds Auster to a roster of American writers who writes about America so as to let it stand in for a general, even shared experience. The local shape of an American author in a peripheral critical field like Sweden's is, at any rate, strongly mediated by the relations between two literary core nations, the U.S. and France, in world literary space. But that mediation requires local agents capable of articulating such spatial relations, and that, in turn, has something to do with their own transnational orientations, as they seek to make Swedish the taste that can decide on American wit.

\section{Works Cited}

Andersson, Git. "Han är vår tids Kafka-en äventyrlig skribent." Norrländska Social-Demokraten. 19 June, 1989.

Augustsson, Lars-Åke. "Till ensamheten med kärlek och smärta." Rev. of Stad av glas, by Paul Auster. Expressen 27 Oct. 1988.

Auster, Paul. The Art of Hunger: Essays, Prefaces, Interviews. San Diego: Sun and Moon Press, 1992.

Begley, Adam. "Case of the Brooklyn Symbolist," New York Times 30 Aug., 1992. 30 May, 2007. <http://www.nyt.net> 
Broady, Donald and Mikael Palme. "Inträdet. Om litteraturkritik som intellektuellt fält." Kulturens fält. Ed. Donald Broady. Göteborg: Daidalos, 1998. 173-215.

Casanova, Pascale. The World Republic of Letters. 1999. Trans. M. B. Debevoise. Cambridge: Harvard UP, 2004.

Fioretos, Aris. "Aris Fioretos." 30 May 2008. <http://www.arisfioretos.com/>

Fioretos, Aris. "Konsten att leva: Om Paul Auster." Artes 2 (1990): 63-64.

Fioretos, Aris. "Ordens hunger." Tidskriften 90tal 8 (1993): 22-23.

Forser, Thomas. "Tabloidiseringen av det litterära samtalet: Om kritiken, dess villkor och former." Tidskrift för litteraturvetenskap 27.1 (1998): 62-86.

Forser, Thomas. Kritik av kritiken: 1900-talets svenska litteraturkritik. Gråbo: Anthropos, 2002.

Gedin, David. "En amerikansk Kafka som bejakar tystnaden." Sydsvenska Dagbladet 29 June, 1989.

Gedin, David. Fältets herrar:Framväxten av en modern författarroll: Artonhundraåttiotalet. Stenhag: Symposion, 2004.

Gellerfelt, Mats. "Paul Auster och storstadslabyrinten." Svenska Dagbladet 16 March, 1990.

Gellerfelt, Mats. "Paul Auster och tomheten i livets mitt." Svenska Dagbladet 2 May, 1993. Indiana, Gary. "Pompous Circumstance: Paul Auster Indulges Himself." Rev. of Moon Palace. Village Voice, 4 Apr. 1989, 45.

Jordebo, Lena. "The Passion of Maria." Dagens Nyheter 1 March, 2004. <www.dn.se>

Lundén, Rolf. "American Literature in Translation," Images of America in Scandinavia. Ed. Poul Houe and Sven Hakon Rossel. Amsterdam: Rodopi, 1998. 128-144.

Lundkvist, Artur. "Flicka med framtid." Arbetet 7 May, 1981.

Malmberg, Carl-Johan. "Underhållande jakt på den heliga Graal.” Rev. of Da Vinci-koden by Dan Brown. Svenska Dagbladet 27 Feb. 2004. Mediearkivet. <www.mediearkivet. se>

Merivale, Patricia. "The Austerized Version." Rev. of Beyond the Red Notebook: Essays on Paul Auster by Dennis Barone; Paul Auster--Danilo Kiš Issue. The Review of Contemporary Fiction by Dennis Barone; and L'Oeuvre de Paul Auster: Approches et lectures plurielles by Annick Duperray. Contemporary Literature, 38.1 (Spring, 1997): 185-197.

Mortensen, Per. "Han laddar med egen kanon." Dagens Nyheter 24 March, 2007: 39.

Nordenson, Magdalena. "Vår tids Kafka.” Barometern 14 Oct., 1991.

Roosvald, Ulf. "Den svenska bästsäljarlistan är snart en helsvensk affär." Svensk Bokhandel 20 Dec 2007. <www.svb.se/SvB_papper/147336/Nummer_20/Artiklar_nr_20/153908>

Rydén, Per. Domedagar: Svensk litteraturkritik efter 1880. Lund: Avd. för pressforskning, Litteraturvetenskapliga institutionen, 1987.

Said, Edward. The World, the Text, and the Critic. Cambridge, Mass: Harvard UP, 1983.

Schueler, Kaj. "En modern Kafka.” Svenska Dagbladet 24 Sept. 1989.

Sjöblom, Cecilia. "Paul Auster - en Kafka i New York." Rev. of Stad av glas, by Paul Auster. Aftonbladet 18 Nov. 1990.

Svedjedal, Johan. "Kritiska tankar: Om litteraturkritiken och det litterära systemet." Tidskrift för litteraturvetenskap 27.1 (1998): 49-61.

Svenska förläggareföreningen. "Branschstatistik 2000." 20 March 2008. <http://www.forlaggare.se/files/0/27/SvF2000.pdf>

Svensson, Lars-Håkan. "En amerikansk Kafka.” Sydsvenska Dagbladet 29 Sept., 1991.

Vásquez D'az, René. Oliktänkaren: en bok om Artur Lundkvist. Stockholm: Ordfront, 2006.

Vogel, Viveka "Paul Auster-en Kafka i New York.” Göteborgs-Posten 7 Jan., 1990. 
Vogel, Viveka. "En modern Kafka i Brooklyn.” Nya Wermlands-Tidningen 31 Dec., 1998.

Vogel, Viveka. "Paul Auster-en Kafka i New York." Rev. of Stad av glas, by Paul Auster.

Göteborgs-Posten 7 Jan. 1990. 